\title{
Is dairy wastewater safe for production of edible microbial biomass: A case study of Saras dairy plant at Jaipur, India.
}

\section{¿Son las aguas residuales lácteas seguras para la producción de biomasa microbiana comestible? Un estudio de caso de la planta lechera Saras en Jaipur, India.}

\author{
Suman Gaur ${ }^{1, *}$, Nupur Mathur ${ }^{1}$, Anuradha Singh ${ }^{1}$, Pradeep Bhatnagar ${ }^{2}$ \\ 1- Environmental Molecular Microbiology Laboratory, Department of Zoology, University \\ of Rajasthan,Jaipur-302 004, Rajasthan, India. \\ 2- Dean IIS University, Rajasthan, India. \\ * Author for correspondence, Tel. No.: +91 9799945588; Email: \\ suman.gaur92@gmail.com.
}

\section{ABSTRACT}

Mismanagement of wastewater at large scale may lead to catastrophic environmental and health consequences. Microbial remediation of wastewater is one of the most effective low-cost solutions. There are also initiatives to use wastewater for production edible biomass as an alternative for protein diets. While many researches were geared towards maximum recovery of biomass and applications, less was focused on mutagenicity of dairy wastewater. Wastewater fromone of the largest dairy industries in Rajasthan was evaluated for its suitabilityfor microbial biomass production and mutagenicity. Influent wastewater was collected from Saras dairy plant, Jaipur, for 7 consecutive days. Physiochemical properties of wastewater were examined, such as; temperature, $\mathrm{pH}$, salinity, TSS, TDS, turbidity, conductivity, biochemical oxygen demand (BOD), chemical oxygen demand (COD), total organic carbon (TOC), and total Kjeldahl nitrogen (TKN). SOS chromotest and Salmonella fluctuation test (TA 98, TA 100 and TA 102) were carried out at different concentrations of wastewater to assess mutagenic activity.Results indicated ideal $\mathrm{pH}$, temperature and salinity, for microbial remediation. High TOC and TKN were also observed in the investigated wastewater, which are few of the prerequisites for single cell production. The ratio of BOD and COD was between 0.30.4, making the wastewater ideal for microbial growth. No mutagenic activity was 
observed by SOS chromotest, all three concentrations (C $0.01, \mathrm{C} 0.1$, and $\mathrm{C} 0.2$ ) investigated were $<1.5$ IF. Likewise,mutagenic ratio for all three types of Salmonella revertants were below 1.2 threshold, for investigated concentrations $(C 0.5, C 1$, and $C$ 10) of wastewater. Conclusively, examined influent wastewater is less likely to induce mutagenic activity at the investigated concentration. Through physiochemical analysis, the investigated wastewater assumed to be candidate substrate for microbial biomass production.

Keywords: Dairy wastewater, microbial remediation, mutagenicity, SOS chromotest

\section{RESUMEN}

La mala gestión de las aguas residuales a gran escala puede tener consecuencias catastróficas para la salud y el medio ambiente. La remediación microbiana de aguas residuales es una de las soluciones de bajo costo más efectivas. También existen iniciativas para utilizar aguas residuales para la producción de biomasa comestible como alternativa a las dietas proteicas. Si bien muchas investigaciones se orientaron hacia la máxima recuperación de biomasa y aplicaciones, menos se centró en la mutagenicidad de las aguas residuales de productos lácteos. Las aguas residuales de una de las industrias lácteas más grandes de Rajasthan se evaluaron para determinar su idoneidad para la producción de biomasa microbiana y su mutagenicidad. Las aguas residuales se recogieron de la planta lechera de Saras, Jaipur, durante 7 días consecutivos. Se examinaron las propiedades fisicoquímicas de las aguas residuales, tales como; temperatura, $\mathrm{pH}$, salinidad, TSS, TDS, turbidez, conductividad, demanda bioquímica de oxígeno (DBO), demanda química de oxígeno (DQO), carbono orgánico total (COT) y nitrógeno Kjeldahl total (NKT). La cromotest SOS y la prueba de fluctuación de Salmonella (TA 98, TA 100 y TA 102) se llevaron a cabo a diferentes concentraciones de aguas residuales para evaluar la actividad mutagénica. Los resultados indicaron $\mathrm{pH}$, temperatura y salinidad ideales para la remediación microbiana. También se observaron altos niveles de COT y NKT en las aguas residuales investigadas, que son algunos de los requisitos previos para la producción de células individuales. La proporción de DBO y DQO estaba entre 0.3-0.4, lo que hace que las aguas residuales sean ideales para el crecimiento microbiano. No se observó actividad mutagénica por cromotest SOS, las tres concentraciones ( $C 0.01, C 0.1$ y C 0.2 ) investigadas fueron <1.5 IF. Asimismo, la proporción mutagénica para los tres tipos de revertientes de Salmonella estuvo por debajo del umbral de 1.2, para las concentraciones investigadas ( $\mathrm{C} 0.5, \mathrm{C} 1$ y C 10 ) de aguas residuales. En conclusión, es menos probable que las aguas residuales influyentes examinadas induzcan actividad mutagénica a la concentración investigada. A través del análisis fisicoquímico, las aguas residuales 
Sustainability, Agri, Food and Environmental Research, (ISSN: 0719-3726), 9(3), 2021: 329-346 http://dx.doi.org/10.7770/safer-VONO-art2305331

investigadas se asumieron como sustrato candidato para la producción de biomasa microbiana.

Palabras clave: Aguas residuales de lechería, Remediación microbiana, Mutagenicidad, Cromotest SOS.

\section{INTRODUCTION}

Due to overwhelming increase in global population, dairy industries areobserving rapid growth. Since 1980s, dairy industries in India have experienced more than $50 \%$ increase in demand(Wang and $\mathrm{Li}, 2008$ ). With growing demand and expansion of dairy industries, comes a greater challengein the area ofwastewater management. Production of milk and milk products require high amount of water, for processes such as; pretreatment of dairy products, rinsing of utensils and tools, and cleaning (Kirby et al., 2003; Andrade et al., 2014). According to earlier estimates, amount of water consumed in sanitary activities is almost 2.5 folds higher than final processed milk and milk products(Schifrin et al., 1981; Tsachev, 1982).

Microbes are used for remediation of wastewater, studies showed that they can effectively concentrate, remove and recover contaminants (Riggle and Kumamoto, 2000). Effective remediation of wastewater can also provide valuable biomass that is useful as food, biofuel and pharmaceuticals (Renuka et al., 2014;Choi, 2016). Sustainable treatment of wastewater is largely dependent on recovery of biomass. Many studies indicated potential use of biomass, recovered from treatment of dairy wastewater,for animal, fish and human food (Eliasson, 2015;Slavov, 2017; Kurupet al., 2019). Researchers are exploring microbial biomass as future alternative for source of protein (Ritalaet al., 2017). However, safety and potential toxicity must be investigated before it is used as an alternative diet.

Wastewaters are generally considered toxic to the environment. Presence of heavy metals, endocrine disrupting chemicals and organic substancescauses severe threat to human and ecology (Yu et al., 2019). Many studies have revealed that despite stringent treatment, some toxicants cannot be completely removed from the wastewater (Luo et al., 2014;Arvaniti and Stasinakis, 2015; Falaset al., 2016). Therefore, the use of dairy wastewater for production of single cell protein (SCP)from microbial biomass must be initially investigated for its suitability. In this study, suitability of industrial influent dairy wastewater was investigated from a local plant for potential use as substrate for microbial biomassproduction. 


\section{MATERIALS AND METHODS}

Collection of dairy wastewater: SARAS DAIRY Plant, Jaipur, Rajasthan, India has its own wastewater treatment plant, which consist of influent tank, sludge tank, activated sludge tank and effluent tank. Fresh wastewater discharge is collected in the influent tank which later processed into sludge and activated sludge, finally deposited in effluent tank. Figure 1 depicts schematic representation of outlets of wastewater and treatment at dairy plant. Due to daily rotational changes in the manufacturing of milk products and cleaning activities, fresh influent samples were collected every day for a week (Sunday to Saturday) between 16 April 2017 - 22 April 2017 between 9-12 am. Grab samples were collected during maximum activity. Samples were partitioned into aliquots of clean plastic sampling bottles and stored at $4{ }^{\circ} \mathrm{C}$ until further investigation.

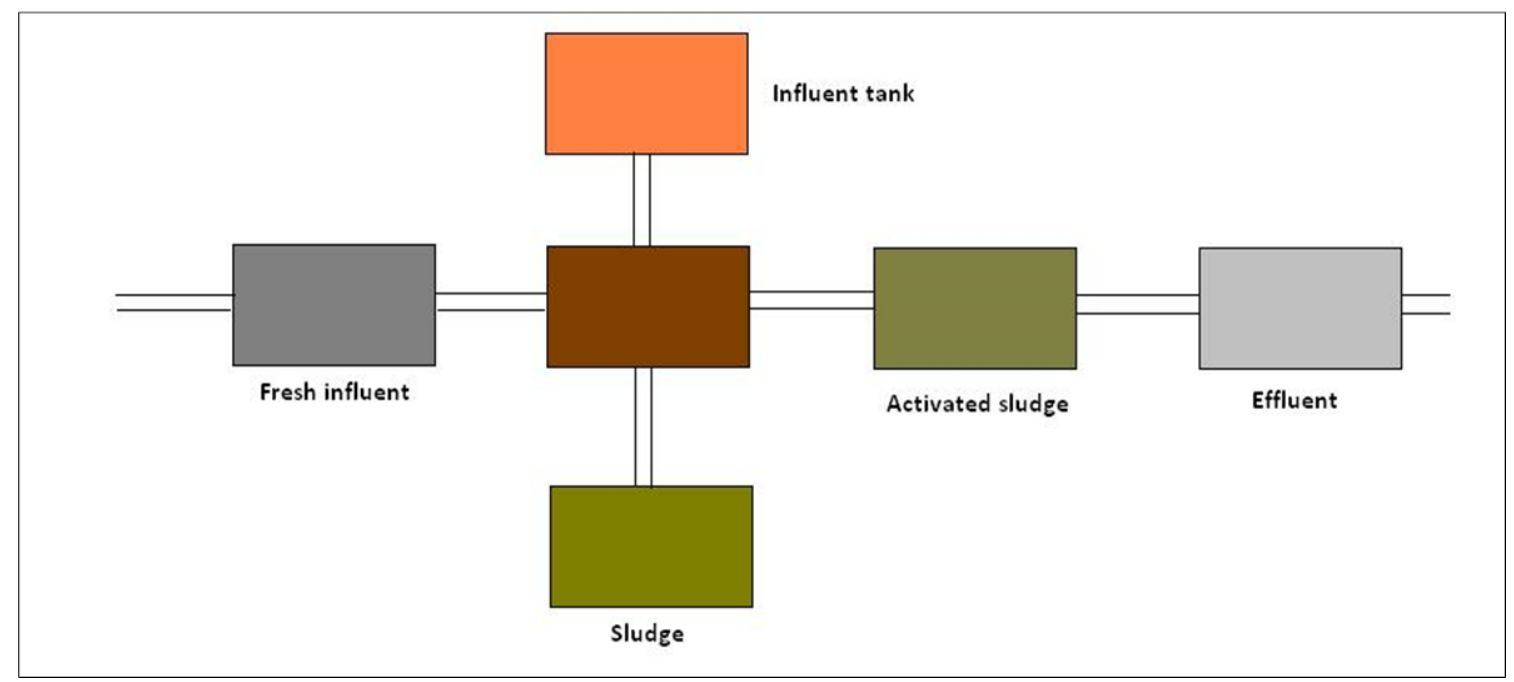

Figure 1: Schematic representation of layout of influent and effluent at Saras dairy plant.

Physiochemical analysis: Temperature, and pHof influent wastewater were determined in situ. Physical properties such as total suspended solids (TSS), total dissolved solids (TDS), salinity, conductivity, and turbidity were determined using standard methods described by Environmental Protection Agency (EPA, 2012) and standard methods of American Public Health Association (APHA, 1985). Likewise, biochemical oxygen demand (BOD), and chemical oxygen demand (COD), total carbon(TC), inorganic carbon (IC) and total nitrogen (TN) were determined as described by APHA(1985). Total organic carbon (TOC) was determined by subtracting IC from TC. 
TN was determined by summing total Kjeldahl nitrogen (Kjeldahl,1883) and nitrogen oxides (APHA, 1985).

Genotoxicity analysisSalmonella fluctuation test: Three strains of Salmonella typhimurium were used for identification of specific mutations, namely, TA98 (frameshift), TA100 (substitution) and TA102 (DNA repair proficient) (Ames et al., 1973; OECD 1997). Experiments were performed according to method described by Legault et al. (1994). Three concentrations of wastewater were examined $(0.01,0.1$, and 0.2 decimals). Plates were incubated at $37^{\circ} \mathrm{C}$ for 3-5 days. For each strain separate positive controls were used, such as; for TA98-2-nitrofluorene ( $50 \mathrm{ng} / \mathrm{ml})$, TA100-sodium azide $(5 \mathrm{ng} / \mathrm{ml})$ and TA-102mitomycin $\mathrm{C}(1 \mathrm{ng} / \mathrm{ml})$. A specific medium was used containing small amount of histidine which allow bacteria to grow and mutate. This medium used $\mathrm{pH}$ sensitive indicator which develop colour from yellow to purple. In the fluctuation medium, colours developed in yellow or partial yellow were considered positive and purple colour was considered negative. All experiments were carried out in triplicates for robust statistical comparison. Mutagenic ratio (MR) was estimated as follows:

$M R=$ Number of positive revertants in test sample/Number of positive revertants in negative control

SOS chromotestTester strain for SOS chromotest was procured commercially. Assay was performed based on method described by Quillardet and Hofnung (1985) with slight modifications. Modification in the method was guided by two other methods, one, Mersch-Sundermannet al. (1991)and Kevekordeset al (1999). Activity of $\beta$-galactosidase was estimated spectrophotometrically at $405 \mathrm{~nm}$, similarly, phosphatase alkaline activity was also estimated at $405 \mathrm{~nm}$. Sample were tested against blank for concentration 0.5 $(50 \%), 1(100 \%)$, and 10 (10 fold concentrated). Genotoxicity activity was calculated by following formula:

$$
\begin{gathered}
R c=\beta \mathrm{Gal} \frac{1}{P A L} \\
I F=\frac{R c}{R o}
\end{gathered}
$$

Statistical analysis: The results were expressed as the Mean \pm SD, and $p<0.05$ was considered significant. Radar plot was applied to envisage asymmetrical variation in physiochemical properties. To establish concentration wise toxicity and/or mutagenicity, Tukey's multiple data test (MINITAB) was applied. In addition, relationshipswithin types 
of mutations (TA98, TA100, and TA102) and between SOS chromotest and Salmonella fluctuation test were examined through regression analysis $\left(r^{2}\right)$.

\section{RESULTS}

Characterization of wastewater: Temperature, $\mathrm{pH}$, turbidity, total dissolved solids, salinity, conductivity, and total suspended solids of influent wastewater are shown in Table 1. Measurement of BOD and COD was $1445.00 \pm 30.00 \mathrm{mg} / \mathrm{l}$, and $4410.00 \pm 60.00 \mathrm{mg} / \mathrm{l}$, respectively. Level of TC was measured as $22857.14 \pm 4582.00 \mathrm{mg} / \mathrm{l}$. Likewise, amount of TOC and IC was calculated as $21523.81 \pm 4581.99 \mathrm{mg} / \mathrm{l}$, and $1333.33 \pm 769.80 \mathrm{mg} / \mathrm{l}$, respectively. Amount of total Kjeldahl nitrogen was $338.81 \pm 11.18 \mathrm{mg} / \mathrm{l}$; whereas, nitrogen oxides was recorded as $437.86 \pm 5.90 \mathrm{mg} / \mathrm{l}$. Therefore, total nitrogen (TN) was noted as $776.67 \pm 10.82 \mathrm{mg} / \mathrm{l}$ (Table 1 ). Radar plot for parameters ( $\mathrm{pH}$ temperature, turbidity, TDS, salinity, conductivity, BOD, COD, and TSS) indicated a clear stretch of upward variation for three distinct parameters i.e. BOD, COD, and TSS (Figure 2).

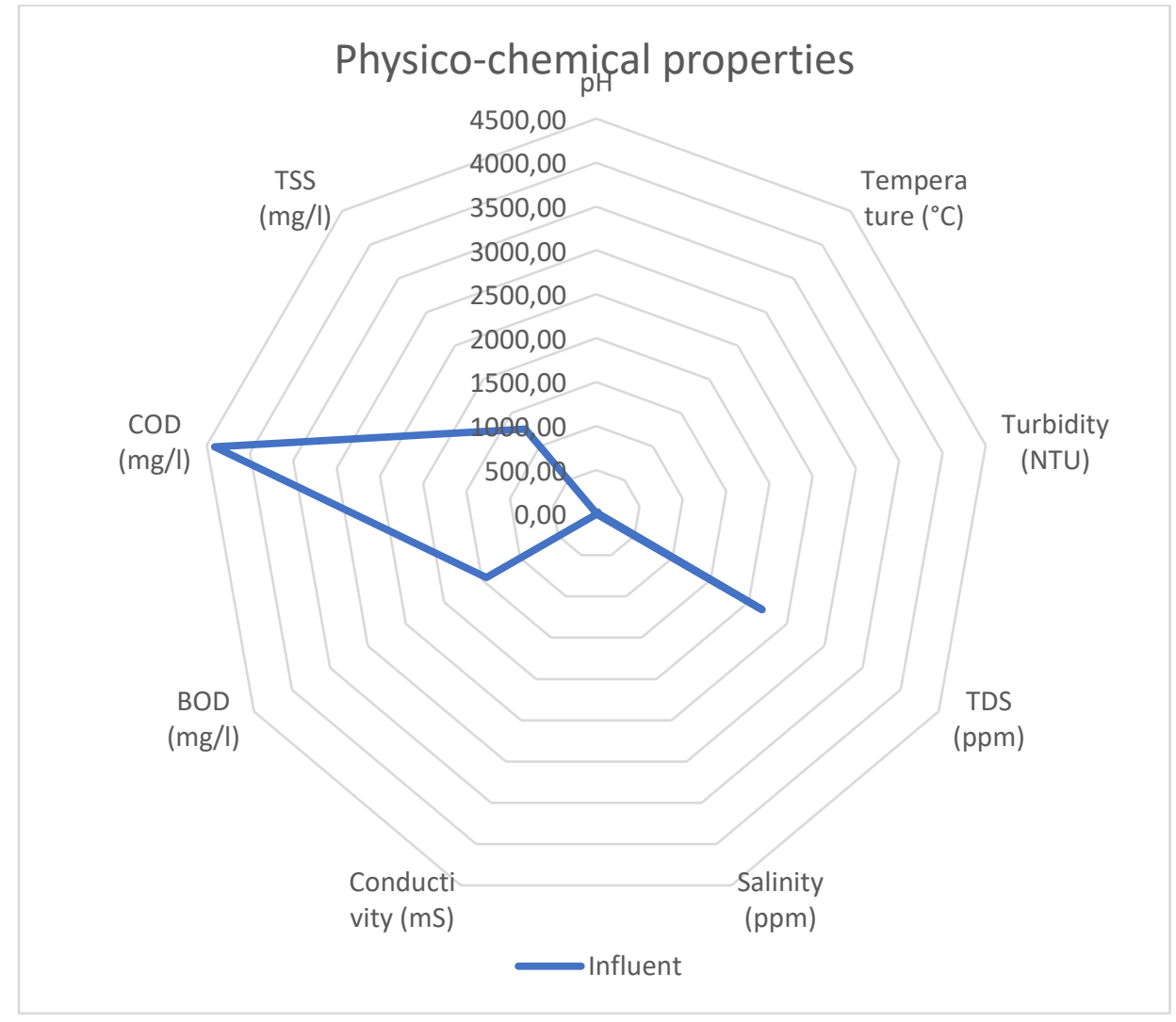

Figure 2: Physiochemical properties of dairy wastewater before (influent) and after treatment (effluent). Properties investigated in the plot are $\mathrm{pH}$, temperature, turbidity, TDS, salinity, conductivity, BOD, COD and TSS. 
Table 1: Physiochemical analysis of dairy wastewater collected during period of one week.

\begin{tabular}{lc}
\hline Parameters & Influent \\
\hline pH & $6.4 \pm 0.1 .00$ \\
Temperature $\left({ }^{\circ} \mathrm{C}\right)$ & $28 \pm 2.00$ \\
Turbidity $(\mathrm{NTU})$ & $25 \pm 0.85$ \\
TDS (ppm) & $2180.00 \pm 50.00$ \\
Salinity $(\mathrm{ppm})$ & $1.2 \pm 0.73$ \\
Conductivity (mS) & $3.15 \pm 1.00$ \\
BOD (mg/l) & $1445.00 \pm 30.00$ \\
COD (mg/l) & $4410.00 \pm 60.00$ \\
TSS (mg/l) & $1260.00 \pm 20.00$ \\
TC (mg/l) & $22857.14 \pm 4582.00$ \\
TOC (mg/l) & $21523.81 \pm 4581.99$ \\
IC (mg/l) & $1333.33 \pm 769.80$ \\
Total nitrogen (mg/l) & $776.67 \pm 10.82$ \\
Total Kjeldahl nitrogen (mg/l) & $338.81 \pm 11.18$ \\
NOx (mg/l) & $437.86 \pm 5.90$ \\
\hline
\end{tabular}

SOS chromotest: For all three concentrations of dairy influent, induction factors were noted as $1.08 \pm 0.005,1.14 \pm 0.03$, and $1.21 \pm 0.04$, respectively. A threshold was set before experiment to confirm particular concentration as toxic. Since ' $R O^{\prime}$ (negative control) was inversely proportional to IF, values greater than ' 1 ' could only be considered as positive. However, considering limitations due to human error, a threshold of value $<1.5$ IF was considered non-inducing. No concentration was measured above 1.5 IF, nonetheless, as the concentration increased a gradual increase in IF was noted(Figure 3).

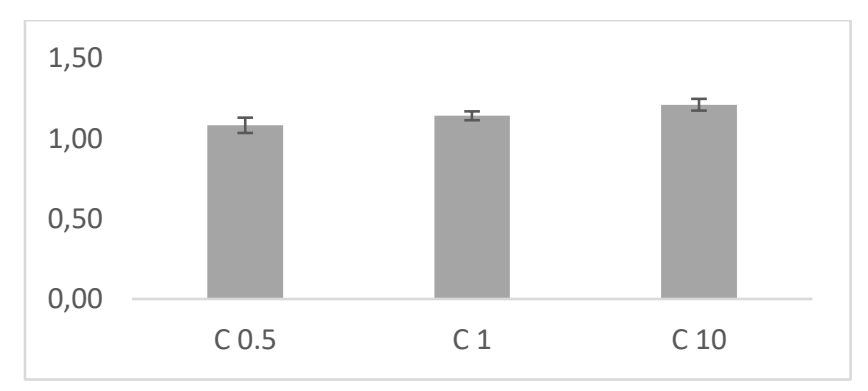

Figure 3: SOS chromotest of dairy wastewater sample collected over a period one week at various concentration. Where, C $0.5=$ Concentration $50 \%, C 1=$ Concentration $100 \%$, and C $10=$ Concentration $1000 \%$. Induction factor (IF) $>1.5$ was considered significant. 
Salmonella fluctuation test: Frameshift mutations in TA98 were recorded with mutagenic ratio of $0.48 \pm 0.16,0.91 \pm 0.15$, and $0.80 \pm 0.31$ for $1 \%, 10 \%$, and $20 \%$ influent concentration, respectively. Fluctuation within various concentration of wastewater was found in TA98 strain. Significant variation was noted in wastewater of concentration $10 \%$ $(p=0.003)$ and $20 \%(p=0.014)$, when compared with lowest concentration of wastewater (i.e. $1 \%$ ) (Figure 4). Likewise, MR of substitution mutation (TA100) was recorded as $0.85 \pm 0.23,1.03 \pm 0.21$, and $1.04 \pm 0.32$ for $1 \%, 10 \%$, and $20 \%$ influent concentration, respectively. Significant variation in mutagenic ratio was observed at $10 \%$ influent concentrations when compared with $1 \%$ influent $(p=0.013)$. Whereas, no significant variation was observed at $20 \%$ influent concentration when compared to $1 \%$ influent $(p=0.298)$ (Figure 4). Mutagenic ratio recorded for TA102 was $1.04 \pm 0.18,0.90 \pm 0.20$, and $1.06 \pm 0.13$ for $1 \%, 10 \%$, and $20 \%$ influent concentration, respectively. No significant variations inestimated mutagenic ratio of $10 \%$, and $20 \%$ influent were observed comparing to $1 \%$ concentration (Figure 4 ).

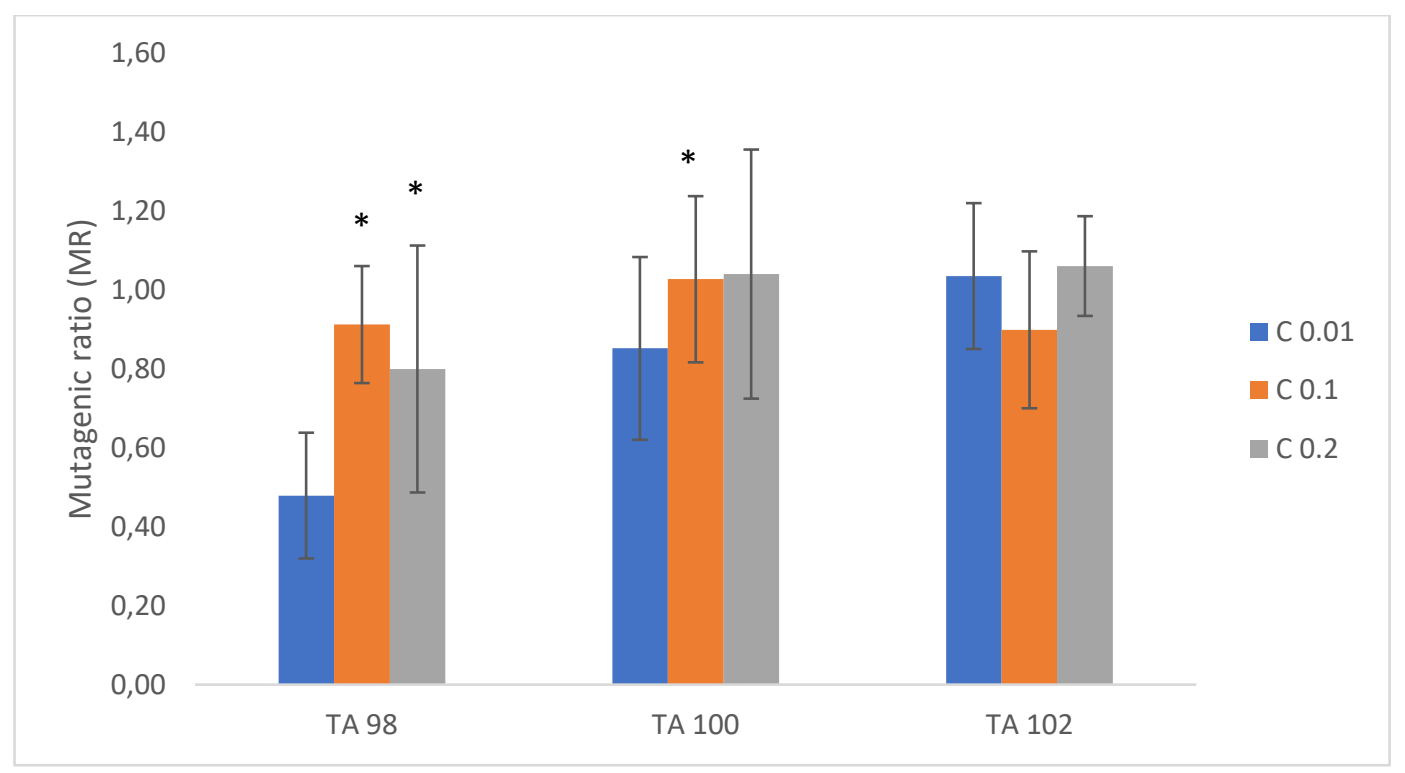

Figure 4: Mutagenic ratio (MR) of dairy wastewater was measured by Salmonella fluctuation test (SFT) for strains TA 98, TA 100, and TA 102. Where, C $0.01=$ Concentration $1 \%$, C $0.1=$ Concentration $10 \%$, and C $0.2=$ Concentration $20 \%$.

$* p<0.05$ (Base concentration was C 0.01)

All three types of mutations (TA98, TA100, and TA102) were evaluated for potential relationship and strength of relationship. Regression analysis indicated strong relationship 
between observed mutagenic ratios for each type of mutation $\left(r^{2}=0.904\right)$ (Figure $5 \mathrm{~A}$ ). Extremelystrong association between induction factors (IF) measured by SOS chromotest and mutagenic ratios (MR) of Salmonella fluctuation tests were noted $\left(r^{2}=0.998\right)$ (Figure 5B).

\section{DISCUSSION}

Industrialization has been associated with increasing global wastes.Despite utilization of green technologies, industries continue to generate wastes and wastewater (Ghosh, 2005). Toxic wastewater can contaminate soil (Ashraf et al., 2014), rivers (Edokpayiet al.,2017), and groundwater(Muamar et al., 2014; Li et al., 2017), creating severe health issues for humans. Dairy industries are one of the most water consuming and wastewater producing industries (Boguniewicz-Zablockaet al., 2019). Thus,toxicity evaluation and effective treatment of wastewaters is prerequisite for industries to enjoy sustainable growth. Microbial remediation of wastewater is one of the widely accepted methods for its low cost and production of biomass. Use of biomass as an alternative for existing protein-energy diet is widelyresearched around the globe (Chisti, 2007). However, presence of toxic compounds in the wastewater and its long-term effects on consumers are not well investigated.
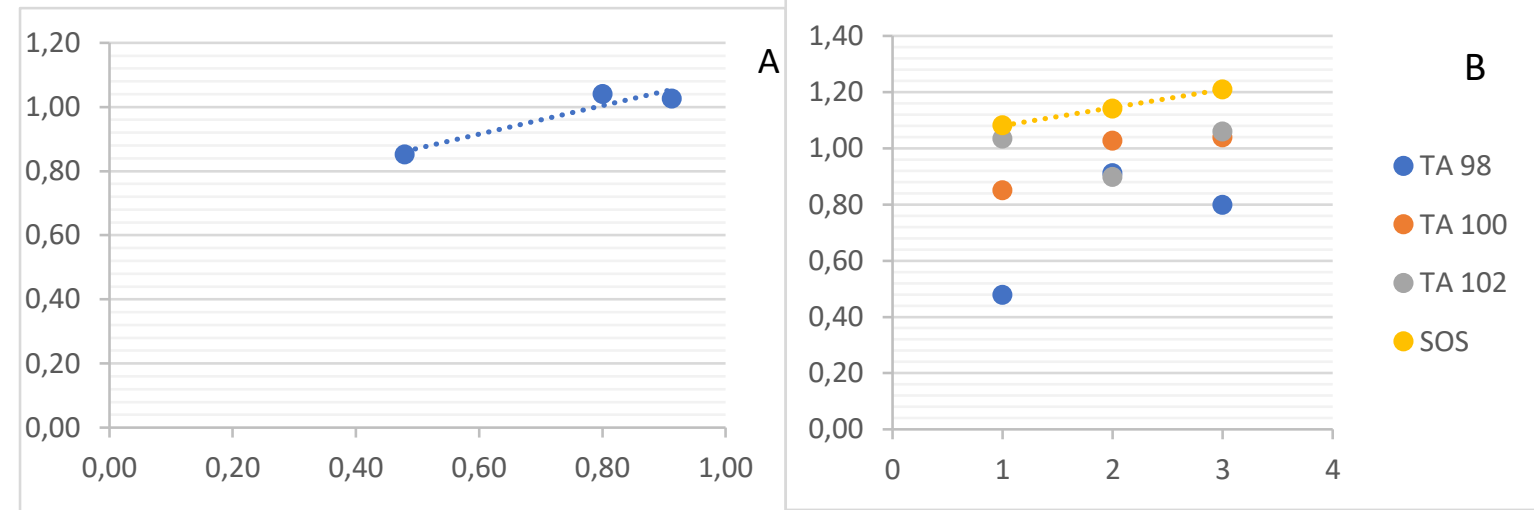

Figure 5: A. Associations between mutagenic ratio of dairy wastewater in various Salmonella strains (TA 98, TA 100, and TA 102). B. Linearity test between variations recorded in induction factors (IF) and mutagenic ratios (MR).

The influent wastewater was slightly acidic but close to neutral. This could be due to release of certain amount whey in the wastewater.Previous studies have also shown 
Sustainability, Agri, Food and Environmental Research, (ISSN: 0719-3726), 9(3), 2021: 329-346 http://dx.doi.org/10.7770/safer-VONO-art2305338

that dairy plant discharge certain amount of whey in the wastewater that leads to reduction in $\mathrm{pH}$, ranging between 5.9 and 6.6 (Tsachev, 1982; Venetsaneaset al., 2009). Mild reduction in $\mathrm{pH}$ of wastewater was also indicative of low use of detergents and other cleaning agents (Slavov, 2017).Struk-Sokolowskaet al. (2017) explained that dairy wastewater by default usually have high temperatures. One of the reasons for the higher temperature of fresh wastewater (influent) is due to use of warm water for processing and cleaning and also due to plumbing ductal system (Davis, 2010).Slightly higher temperature of the influent wastewater was recordedcompared to effluent wastewater at the same site.

According to World Health Organization (WHO, 2003), concentration below 1000 $\mathrm{mg} / \mathrm{l}$ of TDS is considered safe. The TDS value recorded in the study exceeded the limit set by WHO (2003). However, high TDS in wastewater is important for biological growth and also decay of organic matters (Choi et al., 2014). Likewise, wastewater is considered high in salinity (McCartney et al., 2008). High salinity is not favourable for microbial growth, due to negative osmotic potential which encourages plasmolysis (Yan et al., 2015). Low salinity was recorded in this study which is in line with previous studies (Sioudet al., 2016; Verma and Singh, 2017; Verma and Singh, 2018).

Moderately high BOD in influent wastewater was recorded; an indication of existing microbial activity (Garcha et al., 2016). Extremely high level of COD was recorded when compared with the values ofYonaret al. (2018), that recorded COD values of 2000-3000 $\mathrm{mg} / \mathrm{l}$ in various dairy plants in Middle Eastern and European countries.The high COD could be due higher discharge of wasted milk and milk products(Ritambharaet al., 2019). Jaipur is one of the driest cities in India, hot weather and unavailability of refrigerated transportation is common in the area. Mishandling and unorganised transportation of raw milk from production farm to dairy plantcould bethe reason of high COD. Besides, use of large amount of disinfectants containing oxidizing agents could also be one of the reasons behind high COD.

The BOD and COD ratio was ideal for microbial growth; ranging between 0.3 and 0.4 (Bouknanaet al., 2014). The ratio also depends on the existing microbial population in the wastewater. Selected growth of microbial population in the candidate wastewater can significantly alter the BOD/COD ratio (Dhallet al., 2012).

High level of TOC was also recorded in the wastewater. Main sources of TOC in dairy wastewater are detergent, pesticides, industrial chemical and chlorinated compounds. Use of these synthetic compounds in dairy plants is important and vital to maintain hygiene and safety of products (Ojo-Omoniyi, 2013). Presence of high TOC in influent wastewater is indicative of accommodation of selective microbial population. 
Previous studies have shown that pesticides affect microbial population significantly by suppressing one type of microbes but at the same time stimulating other types of microbes (Schäferet al., 2012; Muturi et al., 2017).

Role of nitrogen in wastewater is very important for bioremediation. Many microorganisms utilize derivatives of nitrogen both organic and inorganic to achieve optimal growth(Grunertet al., 2016).Lower values of TKN was recorded compared to previous studies (Bohnenstengelet al., 1999; Kraal et al., 2009). This could be attributed to low discharge of whey into the wastewater. Britzet al. (2006) reported that high release of whey in the wastewater led to high TKN level (1462 mg/l). Interestingly, consumption of whey and whey protein in India have increased by $10-15 \%$ in recent times (www.thehindubusinessline.com > article23731734). Though the values recorded in this study varied from Britzet al. (2006), Fang (1990) and Henaet al. (2015) reported similar level of TKN in the dairy wastewater. High level of nitrogen oxides recorded in this study was in accordance with previous study carried out by Dragičevićzet al. (2010). Remarkably, cheese whey water contains higher amount of total nitrogen compared to dairy wastewater(Tirado et al., 2018). Notably, high level of NOx causes toxicity in human if ingested in large quantity (Craunet al., 1981; Jaffe, 1981).

SOS chromotest were below 1.5 IF threshold and are thus considered safe and nontoxic at the doses investigated. However, the results indicated a dose dependent increase in the induction factor (IF). Where, the lowest dose resulted in minimum induction factor and the highest concentration of dairy wastewater resulted in maximum induction factor. Previous studies recorded genotoxicity of wastewater at a lower threshold (such as; IF = 1.2) (Legault et al., 1996; Kocaket al., 2010). Interestingly, if the lower threshold was taken in to account, influent wastewater of $C 1$ and $C 10$ concentrations may be considered as genotoxic.

The results for frameshift mutations (TA 98) indicated fluctuation in mutagenic ratio at concentrations $C 0.1$ and $C 0.2$. Remarkably, Frameshift mutation is sensitive to mutagens and thus causing alterations in reading frames (Griffiths et al., 2000). Occurrences of spontaneous mutations are commonly found in prokaryotes, more specifically, in Salmonella typhimurium, the rate is in the range of $1-0.34 \times 10^{-10}$ (Schroeder et al., 2018). Thus, a threshold MR must be applied for acceptable fluctuations. To observe significant impact of frameshift mutation, ratio of numbers revertants in test sample and in negative control must exceed the value of ' 1 '. Therefore, to ensure minimum error, the value of mutagenic ratio must exceed at least 1.2 MRwhich was not recorded at any concentrations of influent wastewater. 
The results also recorded significant increase in MR of TA 100 (substitution mutation) at $C 0.1$ concentration. Nonetheless, no fluctuation was observed at higher concentration (i.e.C 0.2 concentration). Thus, it is highly unlikely that a lower concentration would show greater MR than higher concentration. Substitution mutation is mostly caused by radiation, reactive oxidative molecules, and/or mutagens (Iengar, 2012). Interestingly, not all mutagen chooses similar pathway to induce genetic alterations, thus each Salmonella revertants were targeted by different mutagens in this study. This observation in TA 100 could be a result of a spontaneous mutation (Koch et al., 1994). It could be hypothesized that there was no induction of substitution mutation by influent wastewater. Similarly, no significant fluctuations was recorded in TA 102 strain (DNA repair proficiency), which confirms our results of SOS chromotest. Results indicated strong positive association between variables indicating clear association between mutagenic ratios of all three types of revertants. Strong association between SOS chromotest variables and each type of revertants was also observed. Strong relatedness between two separate parameters is possible in two cases, 1 ) there is no change in status of result comparing to blank, or 2) there is positive correlation between alterations in results. In this case, it is assumed that there was no substantial mutagenic activity present in influent wastewater, at least at the investigated concentrations.

In conclusion, there is a strong possibility of utilization of influent dairy wastewater as substrate for microbial biomass production. Characteristics such as; near neutral $\mathrm{pH}$, low salinity, high TOC, and high level of TKN, of investigated wastewater makes it a suitable for production of microbial biomass. The BOD and COD ratio in the investigated wastewater was also ideal for microbial growth. This study confirmed that it is highly unlikely that the influent wastewater would cause any mutagenic activity at its natural concentration. Thus, the influent dairy wastewater can be recycled asa potential substrate for large scale microbial biomass production.

\section{ACKNOWLEDGEMENTS}

The authors are thankful for financial support provided by CSIR-UGC-JRF. We also give our sincere thanks to CAS, Department of Zoology, University of Rajasthan, Jaipur, for providing basic laboratory and infrastructure facility and Head, Department of Zoology, University of Rajasthan

\section{REFERENCES}

Ames, B.N., Lee, F, D., and Durston, W.E. 1973. An improved bacterial test system for the detection and classification of mutagens and carcinogens. Proceedings of the National Academy of Sciences U S A 70(3): 782-786. 
Andrade, L.H., Mendes, F.D.S., Espindola, J.C., and Amaral, M.C.S. 2014. Nanofiltration as tertiary treatment for the reuse of dairy wastewater treated by membrane bioreactor. Separation and Purification Technology 126: 21-29.

APHA-AWWA-WPCF. 1985.Standard methods for the examination of water and wastewater, 16th ed. American Public Health Association, Washington DC.

Arvaniti, O.S., and Stasinakis, A.S. 2015. Review on the occurrence, fate and removal of perfluorinated compounds during wastewater treatment. Science ofthe Total Environment 524: 81-92.

Ashraf, M.A., Maah, M.J., and Yusoff, I. 2014. Soil Contamination, Risk Assessment and Remediation, Environmental Risk Assessment of Soil Contamination, Maria C. Hernandez-Soriano, IntechOpen, DOI: 10.5772/57287.

Boguniewicz-Zablocka, J., Klosok-Bazan, I., and Naddeo, V. 2019. Water quality and resource management in the dairy industry. Environment Science and Pollution Research 26: 1208-1216.

Bohnenstengel, F.I., Wray, V., Witte, L., Srivastava, R.P., and Proksch, P. 1999. Insecticidal meliacarpins (C-Secolimonoids) from Melia azedarach. Phytochemistry 50: 977-982.

Bouknana, D., Hammouti, B., Salghi, R., Jodeh, S., Zarrouk, A., Warad, I., Aouniti, A. and Sba, M. (2014). Physicochemical Characterization of Olive Oil Mill Wastewaters in the eastern region of Morocco. Journal of Materials and Environmental Science 5(4): 1039-1058

Britz, T.J., van Schalkwyk, C., and Hung, Y.T. 2006. Treatment of dairy processing wastewaters. Waste Treatment in the Food Processing Industry pp. 1-28.

Choi, H.J. 2016. Dairy wastewater treatment using microalgae for potential biodiesel application.Environmental Engineering Research 21(4): 393-400.

Choi, J.S., Kim, J.T., and Joo, H.J. 2014.Effect of Total Dissolved Solids Injection on Microbial Diversity and Activity Determined by $16 \mathrm{~S}$ rRNA Gene Based Pyrosequencing and Oxygen Uptake Rate Analysis.Environmental Engineering Science 31(8): 474480.

Chisti, Y. 2007. Biodiesel from microalgae. Biotechnology Advances 25: 294-306.

Davis, M.L. 2010. Water and Wastewater Engineering, Chapter 12-2, General wastewater collection and treatment design considerations. McGraw Hill Professional 7-11. 
Dhall, P., Siddiqi, T.O., Ahmad, A., Kumar, R., and Kumar, A. 2012. Restructuring BOD : COD Ratio of Dairy Milk Industrial Wastewaters in BOD Analysis by Formulating a Specific Microbial Seed. The Scientific World Journal 2012: 1-7.

Dragičevićz, T.L., Hren, M.Z., Dijana, G., Igor, B., and Čurlin, M. 2010. The potential of dairy wastewater for denitrification. Mljekarstvo/Dairy 60(3): 191-197.

Edokpayi, J.N., Odiyo, J.O., and Durowoju, O.S. 2017. Impact of Wastewater on Surface Water Quality in Developing Countries: A Case Study of South Africa. Water Quality in Developing Countries: A Case Study of South Africa, Water Quality, Hlanganani Tutu, IntechOpen, Doi: 10.5772/66561. Available from: https://www.intechopen.com/books/water-quality/impact-of-wastewater-onsurface-water-quality-in-developing-countries-a-case-study-of-south-africa

Eliasson, T. 2015.Dairy waste - Feed for fish? Degree project / Swedish University of Agricultural Sciences, Department of Animal Nutrition and Management, 531. Uppsala, Sweden. https://stud.epsilon.slu.se/8356/11/eliasson_t_150805.pdf

EPA. 2012. Physiochemical properties. In Water: Monitoring and Assessment. Retrieved from http://water.epa.gov/type/rsl/monitoring/vms58.cfm

Falas, P., Wick, A., Castronovo, S., Habermacher, J., Ternes, T.A., and Joss, A.2016. Tracing the limits of organic micropollutant removal in biological wastewater treatment. Water Research 95: 240-249.

Fang, H.P. 1990. Treatment of wastewater from whey processing plant using activated sludge and anaerobic processes. Journal of Dairy Science 74: 2015-2019.

Garcha, S., Verma, N., and Brar, S.K. 2016. Isolation, characterization and identification of microorganisms from unorganized dairy sector wastewater and sludge samples and evaluation of their biodegradability. Water Resources and Industry 16: 19-28.

Ghosh, P. 2005. Foreword.In: Mukesh Doble, Anil Kumar, Biotreatment of Industrial Effluents, Butterworth-Heinemann, pp ix, ISBN 9780750678384,

Griffiths, A.J.F., Miller, J.H., Suzuki, D.T., Lewontin, R.C.,Gelbart, W.M. (2000): An Introduction to Genetic Analysis. 7th edition. New York: W. H. Freeman. https://www.ncbi.nlm.nih.gov/books/NBK21955/

Grunert, O., Reheul, D., Van Labeke, M.C., Perneel, M., Hernandez-Sanabria, E., Vlaeminck, S.E., and Boon, N. 2016. Growing media constituents determine the microbial nitrogen conversions in organic growing media for horticulture. MicrobBiotechnol. 9(3): 389-99. 
Sustainability, Agri, Food and Environmental Research, (ISSN: 0719-3726), 9(3), 2021: 329-346 http://dx.doi.org/10.7770/safer-VONO-art2305343

Hena, S., Fatima, S., and Tabassum, S. 2015. Cultivation of algae consortium in a dairy farm wastewater for biodiesel production. Water Resources and Industry 10: 1-14.

Iengar, P. 2012. An analysis of substitution, deletion and insertion mutations in cancer genes. Nucleic Acids Res. 40(14):6401-6413. doi:10.1093/nar/gks290

Jaffe, E.R. 1981.Methaemoblobinemia. Clinical Haematology 10: 99-122.

Kevekordes, S., Mersch-Sundermann, V., Burghaus, C.M., Spielberger, J., Schmeiser, H.H., Arit, V.M., Dunkelberg, H. 1999. SOS induction of selected naturally occurring substances in Escherichia coli (SOS chromotest). Mutation Research, 445: 81-91.

Kirby, R.M., Bartram, J., and Carr, R. 2003. Water in food production and processing: quality and quantity concerns. Food Control 14: 283-299.

Kjeldahl, J. 1883. Neue MethodezurBestimmung des Stickstoffs in organischenKörpern (New method for the determination of nitrogen in organic substances), ZeitschriftfüranalytischeChemie, 22(1): 366-383.

Kocak, E., Yetilmezsoy, K., Gonullu, M.T., and Petek, M. 2010. A statistical evaluation of the potential genotoxic activity in the surface waters of the golden horn estuary. Marine Pollution Bulletin 60: 1708-1711.

Koch, W.H., Henrikson, E.N., Kupchella, E., and Cebula, T.A. 1994. Salmonella typhimurium strain TA100 differentiates several classes of carcinogens and mutagens by base substitution specificity. Carcinogenesis 15(1): 79-88.

Kraal, P., Klaas, G.J.N., Kaal, J., and Tietema, A. 2009. Carbon respiration and nitrogen dynamics in Corsican pine litter amended with aluminium and tannins. Soil Biology and Biochemistry 41: 2318-2327.

Kurup, G.G., Adhikari, B., and Zisu, B. 2019. Recovery of proteins and lipids from dairy wastewater using food grade sodium lignosulphonate. Water Resources 22: 100114.

Legault, R., Blaise, C., Rokosh, D., and Chong-Kit, R. 1994. Comparative assessment of the SOS chromotest kit and the Mutatox test with the Salmonella plate incorporation (Ames test) and fluctuation tests for screening genotoxic agents. Environmental Toxicologyand Water Quality, 9: 45-57.

Legault, R., Blake, C., and Trottier, S. 1996. Detecting genotoxic activity in industrial effluents using the SOS chromotest microplate assay. Environmental Toxicology and Water Quality 11: 151-165.

Li, Q., Tang, J., Wang, T., Wu, D., Jiao, R., and Ren, X. 2017. Impacts of Sewage Irrigation on Soil Properties of Farmland in China: A Review. Yellow River: 4, 5. 
Luo, Y., Guo, W., Ngo, H.N., Nghiem, L.D., Hai, F.I., Zhang, J.,Liang, S., Wang, X.C. 2014. A review on the occurrence of micropollutants in the aquatic environment and their fate and removal during wastewater treatment. Science of the Total Environment 473-474: 619-641.

McCartney, M.P., Scott, C.A., Ensink, J.H.J., Jiang, B., and Biggs, T.W. 2008. Salinity Implications of Wastewater Irrigation in the Musi River Catchment in India. Ceylon Journal of Science (Biological Sciences) 37: 49-59.

Mersch-Sundermann, V., Kevekordes, S., and Mochayedi, S. 1991. Sources of variability of the Escherichia coli PQ37 genotoxicity assay (SOS chromotest). Mutation Research, 252: 51-60.

Muamar, A., Zouahri, A., Tijane, M., El Housni, A., Mennane, Z., Yachou, H., Bouksaim, M. 2014. Evaluation of heavy metals pollution in groundwater, soil and some vegetables irrigated with wastewater in the Skhirat region Morocco. Journal of Materials and Environmental Science 5: 961-966.

Muturi, E.J., Donthu, R.K., Fields, C.J., Moise, I.K., and Kim, C.H. 2017. Effect of pesticides on microbial communities in container aquatic habitats. Scientific Reports 7: 44565.

OECD. 1997. OECD Guidelines for Testing of Chemicals 471: Bacterial Reverse Mutation Test, OECD Guideline for testing of chemicals. Organization for Economic Cooperation and Development, Paris, France.

Ojo-Omoniyi, O.A. 2013. Biodegradation of synthetic detergents. Chapter 9. In: Biodegradation-Life of Science. InTech pp. 229-249.

Quillardet, P., and Hofnung, M. 1985. The SOS Chromotest, a colorimetric bacterial assay for genotoxins: procedures. Mutation Research, 147: 65-78.

Renuka, N., Sood, A., Prasanna, R., and Ahluwalia, A.S. 2015.Phycoremediation of wastewaters: a synergistic approach using microalgae for bioremediation and biomass generation. International Journal of Environmental Science and Technology 12: $1443-1460$.

Riggle, P.J., and Kumamoto, C.A. 2000. Role of a Candida albicans P1-type ATPase in resistance to copper and silver ion toxicity. Journal of Bacteriology 182: 4899-4905.

Ritala, A., Häkkinen, S.T., Toivari, M., and Wiebe, M.G. 2017. Single Cell Protein-Stateof-the-Art, Industrial Landscape and Patents 2001-2016. Frontiers in Microbiology 13: 8 .

Ritambhara, Zainab, Vijayaraghavalu, S., Prasad, H.K., and Kumar, M. 2019. Treatment and Recycling of Wastewater from Dairy Industry. In: Singh R., Singh R. (eds) 
Advances in Biological Treatment of Industrial Waste Water and their Recycling for a Sustainable Future. Applied Environmental Science and Engineering for a Sustainable Future. Springer, Singapore. https://doi.org/10.1007/978-981-131468-1_4

Schäfer, R.B., Bundschuh, M., Rouch, D.A., Szöcs, E., von der Ohe, P.C., Pettigrove, V., Schulz, R., Nugegoda, D., Kefford, B.J. 2012. Effects of pesticide toxicity, salinity and other environmental variables on selected ecosystem functions in streams and the relevance for ecosystem services. Science of the Total Environment 415: 69-78.

Schifrin, S.M., Ivanov, G.V., Mishukov, B.G., and Feodanov, Yu. A. 1981. Wastewaters from dairy industry. In: Arkhangelskaya EP, editor. Wastewater treatment of meat and dairy industry. Moscow, Russia: Light and Food Industry; pp. 11-19.

Schroeder, J.W., Yeesin, P., Simmons, L.A., and Wang, J.D. 2018. Sources of spontaneous mutagenesis in bacteria.Critical Reviews in Biochemistry and Molecular Biology 53(1): 29-48.

Sioud, O., Beltifa, A., Ayeb, N., and Mansour, H.B. 2016. Characterization of Industrial Dairy Wastewater and Contribution to Reuse in Cereals Culture: Study of Phytotoxic Effect. Austin Journal of Environmental Toxicology 2(2): 1013.

Slavov, A.K. 2017. General Characteristics and Treatment Possibilities of isspiDairy Wastewater - A Review. Food Technology and Biotechnology 55(1): 14-28.

Struk-Sokołowska, J., Rodziewicz, J., and Mielcarek, A. 2017. Effect of dairy wastewater on changes in COD fractions in technical-scale SBR type reactors. Water Science and Technology (1): 156-169.

Tirado, L., Gökkuş, Ö., Brillas, E., and Sirés, I. 2018. Treatment of cheese whey wastewater by combined electrochemical processes. Journal of Applied Electrochemistry 48: 1307-1319.

Tsachev, T. 1982. Dairy industry wastewater treatment. In: Industrial wastewater treatment. Sofi a, Bulgaria: State Publishing House Technique; pp. 239-41.

Venetsaneas, N., Antonopoulou, G., Stamatelatou, K., Kornaros, M., and Lyberatos, G. 2009. Using cheese whey for hydrogen and methane generation in a two-stage continuous process with alternative $\mathrm{pH}$ controlling approaches. Bioresource Technology 100: 3713-3717.

Verma, A., and Singh, A. 2017.Physico-chemical analysis of dairy industrial effluent. International Journal of Current Microbiology and Applied Sciences6(7): 1769-1775. 
Verma, A., and Singh, A. 2018. Physico-chemical and genotoxic analysis of dairy industrial effluent. Journal of Industrial Pollution Control 34(1): 1904-1911.

Wang, Y., and Li, S. 2008. Worldwide trends in dairy production and consumption and calcium intake: is promoting consumption of dairy products a sustainable solution for inadequate calcium intake? Food Nutrition Bulletin 29(3): 172-185.

WHO. 2003. World Health Organization, Guidelines for drinking water, In: Total dissolved solids in Drinking water. Background document for development of WHO Guidelines for Drinking Water Quality.

Yan, N., Marschner, P., Cao, W., Zuo, C., and Qin, W. 2015. Influence of salinity and water content on soil microorganisms. International Soil and Water Conservation Research 3(4): 316-323.

Yonar, T., Sivrioglu, O., and Özengin, N. 2018.Physico-Chemical Treatment of Dairy Industry Wastewaters: A Review. IntechOpen Chapter 10: 179-191.

Yu, Y., Wu, B., Jiang, L., Zhang, X.X., Ren, H.Q., and Li, M. 2019. Comparative analysis of toxicity reduction of wastewater in twelve industrial park wastewater treatment plants based on battery of toxicity assays. Scientific Reports 9(1): 3751 .

Received: $27^{\text {th }}$ August $2020 ;$ Accepted: $16^{\text {th }}$ November $2020 ;$ First distribution: $07^{\text {th }}$ January 2021. 